\author{
Magdalena LESIŃSKA \\ Uniwersytet Warszawski \\ m.lesinska@uw.edu.pl \\ Tomasz STĘPNIEWSKI \\ Katolicki Uniwersytet Lubelski Jana Pawła II \\ tomasz.stepniewski5@gmail.com
}

\title{
SPECYFIKA WSCHODNIEJ GRANICY \\ UNII EUROPEJSKIEJ Z PERSPEKTYWY BEZPIECZEŃSTWA I ROZWOJU
}

ABSTRACT The specific nature of the European Union's eastern border in view of security and development

The shape of the EU's external policy depends upon the state of the EU itself as well. The Union struggles with several overlapping crises of various nature: 1) financial, 2) Brexit, 3) immigration, 4) Russia-Ukraine hybrid war and challenges for European security, 5) crisis of European identity. Changes emerging in the immediate and more distant surroundings of the EU exert a direct impact upon the sense and perception of EU's security. Therefore, the security cannot be simplified to that of the individual member states, but must be considered in broader terms i.e. related to the neighboring regions - the post-Soviet states in this particular case. In view of events and developments of 2016, it can be argued that both southern and eastern neighborhood of the EU are challenged with crises, instability and internal conflicts (political, social and military in nature).

Słowa kluczowe: wschodnia granica Unii Europejskiej, Unia Europejska, Europa Wschodnia, kryzys ukraiński, bezpieczeństwo

Keywords: European Union's eastern border, European Union, Eastern Europe, Ukrainian crisis, security 


\section{GRANICE UNII EUROPEJSKIEJ I EUROPEJSKA POLITYKA SĄSIEDZTWA}

Granice lądowe Unii Europejskiej (UE) to 8 tys. km, a granice morskie są dziesięciokrotnie dłuższe (80 tys. km). Do 1 maja 2004 r. Finlandia, Niemcy, Austria i Włochy strzegły lądowej granicy na wschodzie, która liczyła wtedy około 4 tys. km długości. Po przystąpieniu dziesięciu nowych państw członkowskich w maju 2004 r. miejsce tych czterech państw zajęły Estonia, Łotwa, Litwa, Polska, Słowacja, Węgry i Słowenia. Po przystąpieniu Bułgarii i Rumunii w 2007 r. wschodnia zewnętrzna granica lądowa z Białorusią, Rosją, Ukrainą i Mołdawią wydłużyła się do 6 tys. km. Obecnie wschodnia zewnętrzna granica lądowa Unii biegnie od Morza Arktycznego do Morza Czarnego i Morza Śródziemnego i stanowi poważne wyzwanie związane z jej kontrolą i zarządzaniem procesami migracyjnymi mającymi miejsce na wschodnim pograniczu Wspólnoty.

Rozszerzenia Unii Europejskiej w 2004 i 2007 r. spowodowały, że jej granica zewnętrzna przesunęła się daleko na wschód. Doprowadziło to do zmiany w postrzeganiu przez Wspólnotę jej wschodnich sąsiadów. Zmiana ta, po pierwsze, wynikała z tego, że granice UE zaczęły dotykać obszaru poradzieckiego i czarnomorskiego, w związku z czym zmieniła się jej ocena sytuacji - odległe dotąd i mało istotne dla Unii problemy państw wschodnich pojawiły się w jej bezpośrednim sąsiedztwie i zaczęly oddziaływać na jej sytuację. Po drugie, państwa Europy Środkowej od chwili uzyskania członkostwa (zwłaszcza Polska) starały się wpływać na kształt polityki zewnętrznej UE i podkreślać znaczenie państw Europy Wschodniej (w szczególności Ukrainy) w polityce Unii. Tym samym przyniosło to zakwestionowanie, obowiązującego we Wspólnocie od lat 90. XX w., myślenia w duchu Russia first.

W 2004 r. Unia Europejska stworzyła Europejską Politykę Sąsiedztwa (EPS), której jednym z głównych zadań było osiągnięcie stabilizacji w południowym i wschodnim sąsiedztwie Wspólnoty. Zadanie to miało zostać zrealizowane przez stworzenie wokół granic zewnętrznych UE „kręgu przyjaciól” - stabilnego i w perspektywie demokratyzującego się sąsiedztwa. W następnych latach zgłaszane były liczne projekty dotyczące modyfikacji polityki sąsiedztwa UE w celu uskutecznienia jej oddziaływania na sytuację południowych i wschodnich sąsiadów. Warto wspomnieć tutaj o propozycjach takich jak: EPS Plus (European Neighbourhood Policy Plus) z 2006 r., Synergia Czarnomorska (Black Sea Synergy) z 2007 r., Wzmocniona EPS (Enhanced European Neighbourhood Policy), Unia dla Śródziemnomorza (Union for the Mediterranean) z 2008 r. oraz Partnerstwo Wschodnie (Eastern Partnership) z 2009 r.

Mimo poważnych przemian politycznych na obszarze południowego i wschodniego sąsiedztwa, jakie zaszły w ciągu ostatniej dekady, EPS nie została radykalnie zmieniona, jedynie poddana modyfikacjom, a tym samym nie przyczyniła się do poprawienia sytuacji w regionie, szczególnie w zakresie bezpieczeństwa. Tzw. arabska wiosna, wojna Rosji z Gruzją w sierpniu 2008 r., a następnie wojna hybrydowa Rosji z Ukrainą od 2014 r. potwierdzają, że EPS nie jest polityką efektywną i nie zapobiega konfliktom 
w bliskim sąsiedztwie Unii Europejskiej. Dodatkowo, dokonany przez Komisję Europejską przegląd EPS w latach 2014-2015 potwierdził niewielką skuteczność tej polityki oraz wskazał na konieczność zmian w sposobie jej funkcjonowania. Według Komisji Europejskiej w najbliższych latach EPS winna koncentrować się na stabilizacji, większej współodpowiedzialności, bezpieczeństwie i rozwoju gospodarczym krajów sąsiedztwa. Jak zauważył komisarz UE ds. polityki sąsiedztwa i negocjacji w sprawie rozszerzenia Johannes Hahn, najważniejszym zadaniem $w$ tej chwili jest zapewnienie stabilizacji $w$ naszym sasiedztwie. Konflikty, terroryzm i radykalizacja postaw stanowia zagrożenie dla nas wszystkich. Brak bezpieczeństwa jest też jednak skutkiem ubóstwa, korupcji i ztego sprawowania rzadów. Dlatego tam, gdzie istnieje taka potrzeba, skoncentrujemy sie w kontaktach z partnerami na taczacych nas wspólnych interesach ${ }^{1}$.

Mówiąc o wschodniej granicy UE, należy zaznaczyć, że jeden z głównych projektów Wspólnoty skierowany do państw wschodnich, czyli Partnerstwo Wschodnie, również winien ulec zmianie. Projekt PW ewoluuje w kierunku struktury koncentrycznych kręgów. Powoduje to, że UE musi wziąć pod uwagę interesy państw nim objętych. Niektóre z państw nie są zainteresowane zacieśnianiem współpracy (Armenia, Azerbejdżan, Białoruś), inne z kolei widzą się w strukturach UE (np. Mołdawia, Ukraina, Gruzja). Współpraca ta winna opierać się na zasadzie more for more, czyli więcej reform za więcej środków finansowych. Jeśli UE nie będzie uwzględniać interesów państw PW, projekt ten skazany jest na porażkę.

Partnerstwo Wschodnie powinno zostać dostosowane do nowej rzeczywistości geopolitycznej we wschodnim sąsiedztwie Unii Europejskiej². Wynika to z faktu, że polityka imperialna Rosji stanowi wyznanie nie tylko dla projektu PW, ale także dla państw nim objętych (w szczególności dla Ukrainy, która bez pomocy Zachodu nie będzie w stanie poradzić sobie z sytuacją, w jakiej się znalazła). Jeśli UE chce mieć wpływ na kształt wschodniego sąsiedztwa, musi położyć nacisk na poprawienie stosunków z państwami PW poprzez zaoferowanie im konkretnych warunków tej współpracy, mającej na celu stabilizację polityczną, ekonomiczną i bezpieczeństwo tego obszaru. Bez pomocy ze strony UE państwa te będą coraz bardziej uzależniały się od Rosji. Polityka tego kraju wobec regionu jest skuteczna, gdyż: 1) gospodarki państw PW są słabe i podatne na wpływy rosyjskie, 2) polityczna korupcja i autorytarny system rządów w państwach PW również sprzyjają interesom Rosji. Co bardzo istotne, niespełnione oczekiwania państw PW co do pomocy ze strony UE w dalszej perspektywie spowodują, że cały re-

Komisja Europejska, Komunikat prasowy, Przegląd europejskiej polityki sąsiedztwa (EPS): zacieśnione partnerstwo na rzecz silniejszego sasiedztwa, Bruksela, 18 XI 2015, [online] http://europa.eu/rapid/ press-release_IP-15-6121_pl.htm, 26 IV 2016.

2 Szerzej na temat wyzwań i zagrożeń dla bezpieczeństwa obszaru poradzieckiego zob.: Безоnacнocms постсоветского пространства: новые вызовы и угрозы. Security of the Post-Soviet Region. New Challenges and Threats, red. 3. Станкевич, Т. Стемпневски, А. Шабацюк, Аюблин-Москва 2014; C. Marklund, The Return of Geopolitics in the Era of Soft Power: Rereading Rudolf Kjellén on Geopolitical Imaginary and Competitive Identity, „Geopolitics” 2015, Vol. 20, nr 2, s. 248-266, [online] http:// dx.doi.org/10.1080/14650045.2014.928697. 
gion zostanie ogarnięty procesem „deeuropeizacji”. W ten sposób zamiast pożądanej stabilizacji i perspektywicznej demokratyzacji obszar Europy Wschodniej i Kaukazu Południowego będzie zmierzał w kierunku autorytaryzmu, utożsamianego z rządami np. Aleksandra Łukaszenki (Białoruś), Władimira Putina (Rosja) czy też reżimami kaukaskimi (Armenia, Azerbejdżan) oraz środkowoazjatyckimi (Kazachstan, Kirgistan). Brak pozytywnych zmian, reform systemowych na obszarze poradzieckim może skutkować fiaskiem procesu demokratyzacji obszaru byłego ZSRR.

\section{KRYZYSY UNII EUROPEJSKIEJ I KRYZYS UKRAIŃSKI - IMPLIKACJE DLA BEZPIECZEŃSTWA EUROPY WSCHODNIEJ}

Kształt polityki zewnętrznej UE zależy również od kondycji jej samej. Wspólnota zmaga się równocześnie z kilkoma kryzysami. 1) Grexit, czyli wiążąca się z załamaniem finansowym możliwość wykluczenia Grecji ze strefy euro. Co istotne, jeszcze w 2015 r. kryzys strefy euro był w centrum uwagi opinii publicznej i decydentów politycznych, potem jednak został zepchnięty na dalszy plan przez kryzys migracyjny. Nie zmienia to faktu, że państwa członkowskie powinny w dalszym ciągu dążyć do wypracowania wspólnego mechanizmu radzenia sobie z kryzysami występującymi w Unii Gospodarczej i Walutowej; 2) Brexit, czyli Britain's exit, a więc ewentualne opuszczenie UE przez Wielką Brytanię; 3) uchodźcy, a więc masy migrantów napływające z Bliskiego Wschodu (szczególnie z ogarniętej wojną domową Syrii) oraz z Afryki Północnej na terytorium UE - zwłaszcza do Niemiec, Austrii i państw skandynawskich; 4) wojna hybrydowa Rosji z Ukrainą stanowiąca wyzwanie dla bezpieczeństwa europejskiego; 5) kryzys tożsamości europejskiej, który związany jest z samą istotą integracji europejskiej, wartościami, na jakich powinna opierać się Unia, a także z solidarnością społeczności europejskiej wystawianej na próbę w wyniku dojścia do władzy w niektórych państwach członkowskich Wspólnoty ugrupowań populistycznych skrajnie prawicowych, ksenofobicznych, antydemokratycznych etc. Jak słusznie zauważa Jerzy Łukaszewski, Unia, jak każde dzieto ludzi, nie jest modelem doskonatości. Ciagle wymaga i ciagle będzie wymagać ulepszeń, umocnień i dostosowań do nowych okoliczności. Ludzie, od których zależy jej byt i jej przysztość, w Brukseli i w stolicach pañstw cztonkowskich, często nie stoją na wysokości zadania, nie doceniaja powotania Unii, nie wydają się znać planów Ojców Zatożycieli z lat 1950".

Zmiany, jakie zachodzą w bliższym i dalszym otoczeniu UE, mają wpływ również na poczucie i postrzeganie bezpieczeństwa przez samą Wspólnotę. Kwestia jej bezpieczeństwa nie może odnosić się jedynie do poszczególnych państw członkowskich, lecz powinna być rozpatrywana w szerszej perspektywie - państw sąsiadujących, w tym przypadku należących do obszaru byłego ZSRR. Możemy powiedzieć, że w $2016 \mathrm{r}$. sąsiedztwo zarówno południowe, jak i wschodnie UE opanowane jest przez kryzysy,

T. de Waal, R. Youngs, Reform as Resilience: An Agenda for the Eastern Partnership, Carnegie Endowment for International Peace, 14 V 2015, [online] http://carnegieendowment.org/2015/05/14/ reform-as-resilience-agenda-for-eastern-partnership/i8k4, 17 VI 2015.

4 J. Łukaszewski, Unia i Polska wświecie wstrzasów i przemian, Lublin 2014, s. 20. 
niestabilność i konflikty wewnętrzne (o charakterze politycznym, społecznym, a także militarnym) $)^{5}$. Obecna polityka Rosji wobec Ukrainy powoduje, że istnieje potrzeba dokonana zmiany w podejściu UE wobec wyzwań w dziedzinie bezpieczeństwa oraz jej wschodnich sąsiadów, w szczególności wobec Rosji. Ponadto wojna hybrydowa Rosji z Ukrainą zmieniła sytuację nie tylko obu tych państw, ale również w Europie i na całym świecie. Po raz pierwszy od zakończenia II wojny światowej jedno państwo (Rosja) zaanektowało terytorium innego państwa (Krym należący do Ukrainy) przy użyciu siły. Tym samym w 2014 r. Rosja pogwałciła wiele zasad prawa międzynarodowego publicznego, chociażby wynikających z Karty Narodów Zjednoczonych (rozdziały I, VI i VII dotyczące integralności terytorialnej, suwerenności). W tym samym roku Rosja rozpoczęła wojnę hybrydową w Donbasie, co stało się kolejnym zagrożeniem dla bezpieczeństwa europejskiego. Fakt ten stanowi wyzwanie również dla Sojuszu Północnoatlantyckiego, który odpowiada za zapewnienie bezpieczeństwa na obszarze państw Wspólnoty. Szczyt NATO w Warszawie, zaplanowany na lipiec 2016 r., powinien potwierdzić zmianę w zakresie postrzegania kwestii bezpieczeństwa nie tylko w Europie Wschodniej, ale i na całym kontynencie.

Warto również zauważyć, że w wyniku nakładających się kryzysów w Unii Europejskiej pojawia się jeszcze jeden problem, a mianowicie ścierania się kręgów cywilizacyjnych na obszarze Europy. Do niedawna to rzeka Łaba była granicą podziału Europy na Wschód i Zachód. Jak słusznie podkreśla Adam Krzemiński, dziśn na tym naszym pótwyspie ścierają się nie tyle ptyty geograficzne, ile cywilizacyjnej nierównoczesności. Zarówno w Polsce czy na Wegrzech, jak i w Europie Zachodniej jedni wcią̇̇ żyja w wieku XX - czy nawet $X I X-$ inni $w X X I^{6}$.

\section{PROCESY MIGRACYJNE A BEZPIECZEŃSTWO I ROZWÓJ UNII EUROPEJSKIEJ}

Unia Europejska jest obszarem bezpieczeństwa i dobrobytu gospodarczego i jako taka pozostaje silnym magnesem przyciągającym tych, którzy szukają szansy na lepsze życie. Europa jest jednym z głównych miejsc docelowych w światowym przepływie osób. Liczba osób zamieszkujących w krajach Unii (dane na dzień 1 stycznia 2014) będących obywatelami krajów trzecich wynosiła 19,6 $\mathrm{mln}$ (3,9\% populacji UE), a liczba osób, które urodzily się poza UE - 33,5 $\mathrm{mln}^{7}$. Kraje Unii są w większości państwami imigracji netto (wielkość napływu przewyższa odpływ ludności), choć należy pamiętać, że profil imigracyjny poszczególnych krajów jest bardzo zróżnicowany: procent osób

Szerzej na temat sytuacji i problemów bezpieczeństwa państw południowego i wschodniego sąsiedztwa w: „Rocznik Instytutu Europy Środkowo-Wschodniej” 2015, R. 13, z. 4: European Neighbourhood Policy after the Arab Spring and Russia-Ukraine Hybrid War.

6 A. Krzemiński, Wygaszanie Europy, „Polityka” 2016, nr 14 (3053), s. 61.

7 Eurostat, Migration and migrant population statistics, V 2015, [online] http://ec.europa.eu/eurostat/ statistics-explained/index.php?title=Migration_and_migrant_population_statistics\&oldid $=264684$, 26 IV 2016. 
urodzonych za granicą w Luksemburgu stanowi 36\%, a w Rumunii 0,6\%. W ciągu ostatnich lat największym wyzwaniem dla Unii nie był napływ osób poszukujących pracy (migracje zarobkowe), ale poszukujących azylu. Według danych Eurostatu w 2014 r. podanie o azyl w UE złożyło 626 tys. osób, co stanowi 45-procentowy wzrost w porównaniu z rokiem 2013 oraz 140-procentowy wzrost w porównaniu z rokiem 2010.

W trakcie trwającego obecnie „kryzysu migracyjnego” w maju 2015 r. Komisja Europejska przedstawiła „Europejski program w zakresie migracji”, w którym zdiagnozowane są największe wyzwania stojące przed Unią związane z procesami migracyjnymi. Wskazano na cztery filary lepszego zarządzania migracją: 1) ograniczenie zachęt dla nielegalnych migrantów, 2) zarządzanie granicami - ratowanie życia i zabezpieczanie granic zewnętrznych, 3) zdecydowana wspólna polityka azylowa, 4) nowa polityka dotycząca legalnej migracji ${ }^{8}$. Analizując założenia polityki migracyjnej UE dotyczacej napływów zewnętrznych, warto pamiętać o podstawowym dylemacie, który James F. Hollifield określit jako „liberalny paradoks”, występujący pomiędzy jednoczesną potrzebą otwarcia i zamknięcia państwa na imigrację ${ }^{9}$ Z jednej strony bowiem potrzeby gospodarki i rynku pracy (nieskrępowanego handlu, transnarodowych inwestycji, przepływu usług, towarów i siły roboczej) uzasadniają otwartość na napływ z zewnątrz, z drugiej zaś strony potrzeba wewnętrznej spójności i bezpieczeństwa uzasadnia proces odwrotny - zamknięcie się na imigrację. Państwa członkowskie na poziomie krajowym, jak i Unia na poziomie wspólnotowym starają się sprostać temu wyzwaniu - pogodzenia potrzeb gospodarki z potrzebą poczucia bezpieczeństwa.

Prognozy dotyczące Unii wskazują bowiem jednoznacznie na konieczność napływu imigrantów z państw trzecich: gospodarka jest coraz bardziej uzależniona od miejsc pracy wymagających wysokich kwalifikacji, w najbliższych latach (do 2025) nastąpi gwałtowny wzrost zapotrzebowania na pracowników z wyższym wykształceniem (o 23\%), dodatkowo wszystkie kraje Unii charakteryzuje gwałtownie starzejące się społeczeństwo (bez napłwyu imigrantów liczba ludności w UE w wieku produkcyjnym zmniejszy się w nadchodzącym dziesięcioleciu o $17,5 \mathrm{mln})^{10}$. Imigracja jest zatem traktowana jako ważny sposób na poprawęstabilności systemu opieki spotecznej oraz zapewnienie trwatego wzrostu gospodarczego $U E^{11}$.

$\mathrm{Z}$ drugiej strony równie ważna jak potrzeba rozwoju jest także kwestia bezpieczeństwa wewnętrznego i zewnętrznego Unii. Obecny kryzys migracyjny przedstawiany jest w charakterze zagrożenia, przed którym należy się bronić, a kluczowym „polem walki” staje się granica zewnętrzna, której skuteczna kontrola jest jednym z głównych priorytetów politycznych. W tym celu powołano w 2005 r. specjalną agencję UE Frontex (Eu-

8 European Commission, Communication from the Commission to the European Parliament, the Council, the European Economic and Social Committee and the Committee of the Regions „A European Agenda on Migration", Brussels, 13 V 2015, COM(2015) 240 final.

9 J.F. Hollifield, Immigrants, Markets and States. The Political Economy in Post-war Europe, Cambridge (Mass.) 1992.

10 European Commission, Communication...

11 Tamże. 
ropejska Agencja Zarządzania Współpracą Operacyjną na Zewnętrznych Granicach Państw Członkowskich UE). Wspomniany już „Europejski program w zakresie migracji” jako podstawowe zadanie wymienia wspólne zarządzanie granicami zewnętrznymi, w tym wdrożenie norm UE w zakresie zarządzania granicami czy wzmocnienie zdolności państw trzecich do zarządzania własnymi granicami.

Biorąc pod uwagę obecne kierunki i dynamikę napływów do Unii, priorytetowo traktuje się granicę południową, czyli Morze Śródziemne i Bałkany, jednak dla Polski i regionu Europy Środkowej największe znaczenie ma wschodnia granica zewnętrzna Unii. Istnieje kilka cech, które mają wpływ na inny charakter, rolę i codzienne funkcjonowanie zewnętrznej granicy UE na wschodzie w porównaniu z jej pograniczem południowym. Po pierwsze, ze względu na swój charakter geograficzny - jako granica lądowa - wydaje się łatwiejsza do kontrolowania w praktyce, w porównaniu z morską granicą południową. Po drugie, mimo że sytuacja polityczna krajów sąsiadujących na wschodzie wydaje się bardziej stabilna niż państw Afryki Północnej i Bliskiego Wscho$\mathrm{du}$, to spory terytorialne czy napięcia o charakterze etnicznym i narodowym wewnątrzi międzypaństwowe występują tam regularnie. Konflikty w Czeczenii (1994-1996 i 1999-2003) i w Gruzji (2008) czy trwający obecnie na Ukrainie skutkowały napływem uchodźców i wzrostem nieregularnych (nielegalnych) przepływów na wschodnim pograniczu Unii. Głównym krajem tranzytowym dla imigrantów z dalszych regionów (Kaukazu i Azji Środkowej) jest Ukraina, która jest także obecnie najważniejszym źródeł imigracji zarobkowej do Polski, a także do pozostałych krajów Europy Środkowej.

Dla zapewnienia bezpieczeństwa ochrona granic nie wystarczy, kluczowe znaczenie ma także polityka sąsiedztwa. Ścisła współpraca z krajami pochodzenia imigrantów dotycząca kontroli przepływów migracyjnych jest jednym z priorytetów polityki migracyjnej Unii. Opiera się ona na porozumieniach dwustronnych między UE a krajami trzecimi, jak również sieci partnerstw na rzecz mobilności. Należy tutaj podkreślić, że choć podjęte liczne środki ochronne i ścisła kontrola graniczna skutecznie utrudniają nielegalne przekroczenie granicy obywatelom państw trzecich, to presja migracyjna z południowych i wschodnich peryferii zewnętrznych do Unii nie zmniejszy się w najbliższej przyszłości. Jeśli wziąć pod uwagę realia gospodarcze (rosnące różnice w rozwoju między krajami o niskim dochodzie i o wysokich dochodach) i niepewnej sytuacji politycznej w wielu regionach świata, imigracja zarobkowa i uchodźcza na terytorium UE jest obecnie i zapewne na długo pozostanie kluczowym problemem, któremu Unia musi sprostać, żeby przetrwać. Rozumieją to nie tylko elity polityczne, ale także jej obywatele. W sondażu zleconym przez Parlament Europejski (Eurobarometr) na temat najważniejszych zagadnień, przed jakimi stoi obecnie Unia, na jesieni 2014 r. imigracja zajmowała czwarte miejsce (po gospodarce, bezrobociu i sytuacji finansowej), wiosną 2015 r. znalazła się już na pierwszym miejscu ${ }^{12}$.

12 Standard Eurobarometr 82, Public Opinion in the European Union (Autumn 2014), [online] http:// ec.europa.eu/public_opinion/archives/eb/eb82/eb82_publ_en.pdf, 27 IV 2016; Standard Eurobaro meter 83, Public Opinion in the European Union (Spring 2015), [online] http://ec.europa.eu/pu blic_opinion/archives/eb/eb83/eb83_publ_en.pdf, 27 IV 2016. 
Artykuły składające się na niniejszy tom zostały przygotowane przez badaczy z licznych ośrodków naukowych w Polsce. Oddajemy do rąk Czytelników tom czasopisma „Politeja” poświęcony szeroko rozumianym wyzwaniom i zagrożeniom związanym ze wschodnią granicą Unii Europejskiej, rozpatrywanym w kontekście zmian dokonujących się w polityce krajowej i międzynarodowej, procesów migracyjnych i bezpieczeństwa. Teksty ze względu na podejmowane zagadnienia zostały podzielone na trzy grupy tematyczne: 1) migracje - polityka państwa - granice, 2) Unia Europejska i sąsiedztwo wschodnie i 3) Federacja Rosyjska i obszar poradziecki. Redaktorzy tomu składają podziękowania autorom tekstów oraz wyrażają nadzieję, że spotka się on z życzliwym przyjęciem Czytelników.

Lublin-Warszawa, kwiecień 2016 r.

\section{BIBLIOGRAFIA}

European Commission, Communication from the Commission to the European Parliament, the Council, the European Economic and Social Committee and the Committee of the Regions „A European Agenda on Migration”, Brussels, 13 V 2015, COM(2015) 240 final.

Eurostat, Migration and migrant population statistics, V 2015, [online] http://ec.europa.eu/eu rostat/statistics-explained/index.php?title=Migration_and_migrant_population_statistics \&oldid $=264684$.

Hollifield J.F., Immigrants, Markets and States. The Political Economy in Post-war Europe, Cambridge (Mass.) 1992.

Komisja Europejska, Komunikat prasowy, Przeglad europejskiej polityki sasiedztwa (EPS): zacieśnione partnerstwo na rzecz silniejszego sasiedztwa, Bruksela, 18 XI 2015, [online] http:// europa.eu/rapid/press-release_IP-15-6121_pl.htm.

Krzemiński A., Wygaszanie Europy, „Polityka” 2016, nr 14 (3053).

Łukaszewski J., Unia i Polska wświecie wstrzasów i przemian, Lublin 2014.

Marklund C., The Return of Geopolitics in the Era of Soft Power: Rereading Rudolf Kjellén on Geopolitical Imaginary and Competitive Identity, „Geopolitics” 2015, Vol. 20, nr 2, [online] http://dx.doi.org/10.1080/14650045.2014.928697.

„Rocznik Instytutu Europy Środkowo-Wschodniej” 2015, R. 13, z. 4: European Neighbourhood Policy after the Arab Spring and Russia-Ukraine Hybrid War.

Standard Eurobarometr 82, Public Opinion in the European Union (Autumn 2014), [online] http://ec.europa.eu/public_opinion/archives/eb/eb82/eb82_publ_en.pdf.

Standard Eurobarometer 83, Public Opinion in the European Union (Spring 2015), [online] http://ec.europa.eu/public_opinion/archives/eb/eb83/eb83_publ_en.pdf.

Waal T. de, Youngs R., Reform as Resilience: An Agenda for the Eastern Partnership, Carnegie Endowment for International Peace, $14 \mathrm{~V}$ 2015, [online] http://carnegieendowment. org/2015/05/14/reform-as-resilience-agenda-for-eastern-partnership/i8k4. 
Безопасность постсоветского пространства: новые вызовы и угрозы. Security of the Post-Soviet Region. New Challenges and Threats, red. 3. Станкевич, Т. Стемпневски, А. Шабацюк, $\Lambda$ юбиин-Москва 2014.

Dr Magdalena LESIŃSKA - adiunkt w Ośrodku Badań nad Migracjami Uniwersytetu Warszawskiego. Zainteresowania naukowe: polityka migracyjna państwa i UE, obywatelstwo i polityka naturalizacji, partycypacja polityczna i publiczna migrantów, aktywność polityczna Polonii i Polaków za granicą, polityka państwa wobec diaspory. Autorka kilkudziesięciu publikacji naukowych, w tym monografii Inkluzja polityczna imigrantów we wspótczesnej Europie, Wydawnictwo Naukowe Scholar, Warszawa 2013.

Dr hab. Tomasz STĘPNIEWSKI - politolog i prawnik, kierownik Katedry Studiów Wschodnich, Instytut Nauk Politycznych i Spraw Międzynarodowych, Wydział Nauk Społecznych, Katolicki Uniwersytet Lubelski Jana Pawła II oraz Instytut Europy Środkowo-Wschodniej w Lublinie. Jego zainteresowania badawcze koncentrują się wokół stosunków międzynarodowych na obszarze WNP, wpływu Rosji na sytuację państw poradzieckich, polityki wschodniej Unii Europejskiej oraz bezpieczeństwa europejskiego. Autor artykułów publikowanych w wielu czasopismach naukowych oraz publikacji książkowych, w tym monografii: Geopolityka regionu Morza Czarnego w pozimnowojennym świecie, Lublin-Warszawa 2011, s. 415. 